\title{
ORAL CORRECTIVE FEEDBACK STRATEGIES AND LEARNER UPTAKE IN EFL SETTING
}

\author{
Risna Saswati* \\ STBA LIA \\ Received on 2 August 2021 / Approved on 11 October 2021
}

\begin{abstract}
This study investigates the strategies of oral corrective feedback applied by senior teachers in EFL speaking classes. It is to shed lights on whether those strategies used are effective to lead the repair uptake. Additionally, it is to find out the attempts done by the learners to repair their errors. This study applies qualitative method that uses classroom observations as the technique for collecting the data. The data are taken from speaking classes taught by three senior teachers in three universities. The study reveals that the corrective feedback strategies of correct forms elicited were effective to lead to repair uptake. Those were elicitation, clarification request, repetition, and metalinguistic cue. Related to uptake, the learners attempted to achieve well-formed sentences by the process of Needs Repair to Repair uptake. It involved same errors and acknowledgment for Needs Repair and incorporation, repetition and self-repair for repair uptake. It is recommended that teachers apply the correct form elicited corrective feedback strategies to correct learners' erroneous forms and provide the uptake since it is the learning process.
\end{abstract}

Keywords: oral corrective feedback strategies, learners' uptake, repair, needs repair

\section{ABSTRAK}

Penelitian ini membahas tentang strategi umpan balik dalam pembelajaran berbicara di kelas.Penelitian ini akan menjawab pertanyaan tentang sejauh mana strategi umpan balik dapat memfasilitasi siswa untuk memperbaiki kesalahan yang dibuat dan memformulasikan jawaban yang benar. Hasil dari penelitian ini adalah strategi umpan balik yang telah dipilih guru efektif untuk membantu siswa memperbaiki bentuk Bahasa. Strategi umpan balik yang efektif adalah dengan memberikan strategi elisitasi bentuk bahasa yang benar seperti strategi pengulangan, klarifikasi, elisitasi dan isyarat metalinguistik. Strategi tersebut dapat memberikan kesempatan siswa berusaha memperbaiki kesalahan bentuk bahasa. Siswa berusaha memperbaiki kesalahan dengan cara mengulang dari kalimat yang diberikan guru, memperbaiki sendiri yang pada akhirnya dapat memproduksi kalimat yang benar. Direkomendasikan untuk guru memberikan kesempatan siswa memperbaiki kesalahan dengan menerapkan strategi umpan balik dalam bentuk elisitasi bentuk bahasa yang benar.

Kata Kunci: strategi umpan balik bahasa lisan, bentuk bahasa, elisitasi, perbaikan kesalahan

\section{INTRODUCTION}

Classroom interaction which involves the interaction among learners, teachers and individual learners has its own interactional features. Regarding the objectives, classroom interaction has its own goal to fulfill: pedagogical goal and natural goal. The former is that the language is the goal and the means to achieve the goal (Richards, 2014). The latter is to assist learners to exchange information while engaging in the interaction in order to maintain the interpersonal relationship (Seedhouse, 1996).

To achieve the pedagogical goal, teachers use the target language as the means for giving instructions and directions, modeling target language patterns and giving feedback on student's performance. The language used by the teacher is how teachers

\footnotetext{
*Author(s) Correspondence:

E-mail: risnasaswati@gmail.com
} 
modify their language and use questions and how teachers give feedback to the students. The students learn the language to negotiate classroom interaction with the teacher and other students and to do the tasks. Teacher language use and learners are two key variables out of four variables that are believed can facilitate learning (Liu and $\mathrm{Xu}, 2018$ ).

Studies of classroom talk have rules and conventions, for the language used by the teachers and learners is not natural. Teachers have the role to make communication in the classroom resemble communication outside the classroom. The aim is to prepare students to transfer knowledge learned to the real-life requirements (Van Lier, 1984; Walsh, 2002, Seedhouse and Jenks, 2015). Therefore, there are studies that are concerned about how teachers use the language in classroom interaction. Ellis (2012) mentions three reasons why teachers' use of language become the subject of research. it is the teachers who make the major contribution in the classroom interaction and give inputs to learners. Besides it allows for detailed examination of key aspects of language use and reflects the common approach to researching the L2 classroom. The key aspects are teacher talk, teacher questions, teacher use of L1 and metalanguage, and teacher corrective feedback. As one of the key aspects in classroom interaction, teacher language use is believed to facilitate learning and promote learner's engagement in classroom interaction.

The pattern of classroom interaction reflects the asymmetrical relationship between teachers and learners. Teachers have the responsibility to organize the interaction that occurs in the classroom. Walsh (2011) proposes the features of classroom interaction which are seen from the perspective of teachers. The features are control the interaction, speech modification, elicitation, repair, and IRF (Interaction, Response and Feedback) pattern. IRF pattern is seen based on the structure of classroom interaction that typically occurs in classroom interaction (Sinclair and Coulhard, 1975; Walsh, 2011). It starts by teacher initiates the conversation and follows by learners' responses. Based on learners' responses, teachers give feedback. This structure of classroom interaction is borrowed from Sinclair and Coulthard (1975). This classroom interaction dominates by teachers who control the classroom interaction.

A study about classroom interaction using IRF pattern in a EFL conversation class was conducted by Saswati (2018). The study revealed that the IRF pattern employed by the teacher could facilitate the learner-initiated communication and facilitate the learning opportunities for the learners to engage in classroom interaction. The teachers were to vary the techniques of initiating and giving corrective feedback. The teacher initiation could be in the form of questions not a statement since there was a culture constraint in EFL classes. The learners did not want to talk if the teachers did not ask them. The recommended questions were the referential questions instead of display questions. The feedback is recommended to be provided since learners are to give the opportunities to correct the error they made in order to improve their language.

In Richards (2014), one distinguishing features of language classroom is that language is the goal of the lesson and the means by which this goal is achieved. Teachers use the target language as the means for giving instructions and directions, modeling target language patterns and giving feedback on learner performance. The learners learn the language to negotiate classroom interaction with the teacher and other learners and to do the tasks. The language used by the teacher is how teachers modify their language and use questions and how teachers give feedback to the learners. Corrective feedback plays a role in language teaching and learning. However, little research was conducted to teachers' practices of corrective feedback in students' speaking performance and their uptake. Therefore, this study reports the corrective feedback strategies employed by the teachers effective to lead to repair uptake. Additionally, it sheds lights on the type of the uptake learners make to correct the errors they made.

\footnotetext{
*Author(s) Correspondence:

E-mail: risnasaswati@gmail.com
} 


\section{LITERATURE REVIEW}

\section{Types of corrective feedback strategies}

Classroom discourse is dominated by teachers dealing with learners' errors and it is time consuming. The consideration is whether or not the learners' errors affect the flow of the lesson or not. If it does not, teachers decide not to give corrective feedback. However, in controlled practice activities teacher needs to give corrective feedback to gain the learners' accuracy. While teachers focus on the oral fluency, corrective feedback can be avoided if it does not affect the flow of conversation. What teachers do is they tailor the learners' errors and give the corrective feedback to the moment and promote the opportunities for learning (Van Lier, 1998).

When learners make errors in their utterances, teachers correct them. Ellis (2008) defines that corrective feedback is teachers' responses to learners' utterances that contain errors. Accordingly, teachers' oral corrective feedback means (1) as indication that an error has been made by learners, (2) as a model of a good form, (3) metalinguistic information about the nature of errors. Feedback which is one of the discourse features is categorized into feedback in form and feedback in content. Feedback in content is in the form of acknowledging the correct answers and incorrect answers, praising, repeating, summarizing, criticizing, and modifying a learner's answer. Feedback on form involves decision about whether or not the learners' error should be corrected, what kind of errors should be corrected, and how learners' errors should be corrected (Ellis, 2012). Regarding teachers' strategies of giving feedback, Lsyter and Ranta quoted in Ellis (2012), proposed the types of strategies:

1. Explicit correction: It is the explicit correction of the incorrect form made by the learners. The teacher is to give an indication to learners that what the learners say is not correct.

2. Recast: It is the reformulation of all part what learners say. However, it is to exclude the error that the learners make.
3. Clarification request: It is to indicate to learners either their utterances are understood by the teacher or their forms are erroneous.

4. Metalinguistic feedback: It contains comments, information or questions related to the well-formedness of learners' utterances. It is without explicitly providing the correct form.

5. Elicitation: There are three types under this category: (1) eliciting completion of his/her own utterances, (2) using questions in order to elicit the correct form, (3) asking learners to reformulate his/her utterance.

6. Repetition: The teachers repeat the learners' erroneous utterances.

When teachers give corrective feedback, there is a possibility that learners notice that they commit errors in their utterances. The notice makes them respond to teacher's corrective feedback. Therefore, learners are expected to respond to the information related to language problems they have learned. It is what is called by uptake. The uptake move occurs after the teacher corrective feedback (Ellis, 2012).

\section{Learner Uptake}

Lyster and Ranta (1997) use uptake to refer to learners' responses to teacher's corrective feedback. They add that uptake is the students' attempts or efforts to repair their erroneous forms. If there is no uptake, it means that there is topic continuation. Teachers do not give the opportunities for learners to repair the erroneous forms they made. Uptake is considered successful if the learners can do the correct reformulation based on teachers' corrective feedback. The corrective feedback strategies chosen by the teacher is to lead to successful uptake in which learners reformulate the linguistic problems into the correct ones. Therefore, the learner language development occurs and they can engage in meaningful classroom interaction.

Accordingly, the study of uptake is in relationship with the study of corrective feedback. Some studies reveal that there is relationship between corrective feedback with

\footnotetext{
*Author(s) Correspondence:

E-mail: risnasaswati@gmail.com
} 
the learner uptake (Ellis, Basturkmen, \& Loewen, 2001; Suzuki, 2005). Learner uptake is termed by self-initiated repair and unsuccessful uptake refers to needs-repair. The former consists of repetition, incorporation, and self-repair The latter are acknowledgement, same errors, different errors, off target, hesitation, and partial repair. It is shown by the following table.

Table 2. Types of uptakes move (quoted from Lyster and Ranta in Ellis, 2012)

A. Repair

1. Repetition (e.g., the learner repeats the teacher corrective feedback).

2. Incorporation (e.g., the learner makes the teacher's sentence in corrective feedback become longer).

3. Self-repair (e.g., the learner corrects the error made by him/her as a response to teacher corrective feedback that does not give any correct supply).

4. Peer-repair (e.g., the learner gets the correct supply from his/her peer that has get the error corrected after getting the corrective feedback from the teacher).

B. Needs Repair

1. Acknowledgement (e.g., the learner says 'Yes" or 'No').

2. Same errors (e.g., the learner makes the same error).

3. Different error (e.g., the learner fails to correct his/her error and produce another error).

4. Off-target (e.g., the learner responds to teacher's corrective feedback by circumventing the teacher's form).

5. Hesitation (e.g., the learner hesitates in responding the teacher's feedback).

6. Partial error (e.g., the learner just corrects a part of his/her error).

Ellis (2012) adds that uptake is: (1) learner's move, (2) optional, (3) to occur in an episode in which learners have the gap in their knowledge, (4) to occur as a response to the previous move where the linguistic feature is provided. In short, uptake is a move following the corrective feedback given by the teacher. The strategies decided to be chosen by teachers related to committed errors should be effective to enhance classroom interaction. Corrective feedback plays important role regarding scaffolding given by the teachers. It is expected that learners are able to notice their errors committed and reformulate the correct forms after they get the corrective feedback from the teacher. Teachers need to assist learners to promote learning development (Lyster, Saito and Sato; 2012). Abundant SLA studies reveal that Corrective Feedback (CF, henceforth) plays a role in learner's language development (Lyster and Saito, 2010).
One of the studies was conducted by Amalia, Fauziati, and Marmanto (2019). The study shed lights on the male and female students' preferences on six types of oral corrective feedback given by the teacher. The method of the research applied was the qualitative and the techniques for collecting the data were observation and interviews. The data analysis was to use Interactive Models based on proposed by Miles, Huberman and Sladana (2014). This study revealed that explicit correction was the most preferred one by male students and it was favoured by the teacher. The first type of corrective feedback preferred by the female students was the recast and the second type preferred was the metalinguistic feedback. Additionally, the study found out that both males and females did not like clarification requests and repetition since those two strategies employed by the teachers made the learners confused to respond.

\footnotetext{
*Author(s) Correspondence:

E-mail: risnasaswati@gmail.com
} 
The next study investigated teacher corrective feedback on students' speaking performances and the students'uptakes (Phuang and Huan, 2018). The method employed was descriptive qualitative using classroom observation as data collection technique. The two teachers and fifty students were the participants of the study. The findings showed that clarification request was the strategy that could lead the successful uptakes. The second strategy was the recast. Related to the repair uptake, the metalinguistic strategy was considered to be the most successful at eliciting student repair uptake. The other ones were recast $(49 \%)$, explicit correction $(40 \%)$, clarification request $(33 \%)$, repetition $(27,3 \%)$ and elicitation $(25 \%)$.

This study investigates the strategies of oral corrective feedback applied by senior teachers in EFL speaking classes. It is to shed lights on whether those strategies used are effective to lead the repair uptake. Since corrective feedback is to assist learners to repair the erroneous forms they made, their reaction toward teacher corrective feedback is under investigation. Furthermore, this study is to figure out the learners' attempts to correct their erroneous forms they made during the interaction. The categorization is based on repair and needs repair as the types of uptakes move by Lyster and Ranta (1997). This study is different from the previous studies mentioned based on the participants of the study, the problems investigated and the data analysis methods.

\section{RESEARCH METHODOLOGY}

This study applies descriptive qualitative method to describe corrective feedback strategies employed by teachers in speaking classes. It is to describe whether or not those strategies are effective to lead to repair uptake. Additionally, the attempts to correct the learners' error they made during their interaction is under investigation. Their attempts to correct the errors made are categorized by repair and needs repair as modelled by Lyster and Ranta (1997).
The participants of the research are three experienced Indonesian EFL teachers working at three different universities in Jakarta. They have more than 10 years teaching there. Richards (1998) states that the experienced teachers engage in more improvisational teaching than inexperienced teachers. He argues that this suggests that teachers develop their teaching skills which mean that teachers are able to draw less on pre-active decision making and making use of interactive decisions in order to make it a source of their improvisational performance.

The data are teachers' corrective feedback strategies and learners' uptakes during the speaking classroom interaction. All the data are taken from the video classroom observation and transcription of the class observation. The first step is to interview the teachers. The interview is to find out the classes, the material and the learners attending the classes. This interview is not analyzed. However, it assisted to get the background of the classes studied. The second step is to do classroom observation. During the observation, the field notes and video recording are used. The class activities are video recorded by an assistant, for the researcher can focus on the field notes. The three speaking classes consisting more or less 20 students are observed twice and each session has 100 minutes.

To answer the first research question that is whether the strategies chosen by teachers are effective to lead the repair uptake, the transcription is studied to highlight the strategies used by teachers and the learners' responses. Additionally, the observation's transcription is used to answer the type of repair and needs repair strategies attempted by the learners to correct the errors they made. The transcription is highlighted to identify the strategies and learners' uptake. To present the data, the coding system is not to adopt to any study. The utterances in the episodes in this study are marked down by the erroneous utterances by the learners, the strategies applied by the teachers and the strategies or attempts exhibited by the learners to repair the erroneous utterances made.

\footnotetext{
*Author(s) Correspondence:

E-mail: risnasaswati@gmail.com
} 


\section{FINDINGS AND DISCUSSION}

The first research question is whether the corrective feedback strategies employed are effective to lead the repair uptake. The learners attempted to correct their erroneous forms made. They tried to repair their erroneous forms made. The attempts to repair the errors made was discussed in this segment as the second research question. The following episodes revealed the evidences as the answers of the research problems. The episode is taken from the dialog between teacher A and learner A only. There are no other learners involved in the dialog used for this study. The dialog is dyadic.

\section{Findings}

This part presents seven episodes in the form of dialog between the teacher and learner (dyad). The strategies applied by the teachers, the erroneous utterances made by the learner, and the strategies applied by the learner as their attempts to correct the erroneous utterances made are marked down in the brackets. The description is completed by the turns in which the utterances refer to.

\section{Episode 1}

1. T (Teacher): Okay. so what happened here is that there are two persons. What do you think is the relationship between those two people?

2. S (Student): Friends. (Error)

3. T: The relationship?

(CFClarification Request)

4. S: Friends. (Uptake-Needs RepairSame Error)

5. T: How do you know that they are friends? (CF-Clarification Request)

6. S: Because the guy is asking him to go to England. (Uptake-Repair-Selfrepair)

7. T: Okay. She thinks they are friends not enemies. If they are enemies, you will not ask him to. Okay. And other things that make you think that they are friends? (CF-Repetition) (CFClarification Request)

8. S: They were together. (Uptakerepair-Self-repair)

9. S: I think they're classmates. (UptakeRepair-Self-repair)

10. T: Oh. they're probably classmates. (CF-Metalinguistic Feedback)

In (3) teacher employed clarification request for a content to make sure that the learners understood about what it was discussed. The learners responded to teacher's question. However, they were not sure about it. Another corrective feedback occurred in this episode as stated in (4). Teacher used the clarification request in (5). The learner gave a response by telling the reason in (6). It was the repair uptake by self-repair. It was continued by corrective feedback by repeating the learner's utterance and asking a question as a clarification request in turn 7 . The learners could do self-repair as the repair uptake in turn 8 and 9. To comment their correct answers, the teacher used metalinguistic feedback by giving an opinion about the learner's answer as in (10).

\section{Episode 2}

1. T: Okay. I might not be able to sleep tonight. Once it was talking about relationship. Okay, today we're talking about what is it? relationships. The issue that is very common. Okay I hava a good news relationships is actually a fun thing to talk about, but not bad actually. Relationships is not what you think about. It's about elder people, elder relationships. So let's see or open your book on page 44. So on page 44 you will see there is a table there in the "Did You Know" part. Okay so Novianti, can you read one point inside the box, in the "Did You Know" part.

2. S: The longest marriage on record lasted 86 years. (Error)

3. T: Lasted. (CF-Explicit correction)

4. S: Lasted. (Uptake-repair-repetition)

*Author(s) Correspondence:

E-mail: risnasaswati@gmail.com 
It was between Sir Temuji Bhicaji Nariman and Lady Nariman, who wedded in 1853 when they were five years old.

In Episode 2 in (3), teacher applied explicit correction strategy when learner made mistakes in pronunciation. The learner was able to notice his/her mistakes and repeated his/her pronunciation after the teacher. Teachers employed explicit correction to give feedback in the form. The learner could correct the mispronounced word as the repair uptake as stated in (4).

\section{Episode 3}

1. T : Okay, so you have numbers of the 100 elderly people who were interviewed, 15 preferred to live with their children and grandchildren, 80 preferred to live alone, and five did not have a preference. Let's say we have this fact showing about how do elderly live with their children or grandchildren, but sometimes you don't know the exact numbers. That's the part when you are making generalizations which actually makes your statement become straw-man arguments. So the expressions are take a look. By and large, what is the meaning of by and large?

2. S: Secara keseluruhan. (Error)

3. T: Ya, secara keseluruhan.That's almost like most. For the most part, almost the same for the most part. From the sentence, which one you can use as the by and large or for the most part? From 100 elderly. Let's say we choose to live alone. Which expression you can use here? (CFRecast)

4. S: For the most part. (UptakeRepair-Repetition)

5. T: For the most part, yes. (CFRepetition)

For the most part, elderly in the United States prefer to live.... (CFElicitation)

6. S: Alone. (Uptake-Repair-
Incorporation)
The corrective feedback applied was recast when one of the learners answered teacher's question using Indonesian. It was supposed to be in English (2). Teachers repeated learner's response in Indonesian and translated the expression, by and large, into English; however, he/she explained again the expression that learner B did not understand it. The teacher applied recast as the strategy (in 3 ). To check the learner's comprehension, a question was delivered and repair uptake occurred by repeating the teacher's utterance (4). To mark the correct answer, the teacher repeated the learner's utterance and continued by eliciting as the strategy. The learner was to complete the utterance. The repair uptake was achieved.

\section{Episode 4}

1. T : Okay let's change it. This is another difficult topic, so anyway can you give me something. Forget it. How about in English, how would you say it?

2. S: May I ask? (Error)

3. T: May I ask a question? (CFRepetition)

And then saya mau nanya.

4. S: I'd like to ask. (Error)

5. T: I'd like to ask. (CF-Repetition)

6. T: Can you say I want to ask? (CFClarification Request)

7. S: No. (Uptake-Needs RepairAcknowledgment)

8. T: Why not? (CF-Clarification Request)

9. S: It's not very polite. (UptakeRepair-Self-repair)

10. T: Yeah, it's too frontal. It's too facethreatening.

feedback). What else?

In episode 4 in (3), teacher employed repetition as her/his corrective feedback strategy to correct the learner's error. There was no uptake. The teacher continued to another question. However, the learner made an error on the pronunciation. The repetition was chosen as the corrective feedback as stated in turn 5. However, there was no

*Author(s) Correspondence:

E-mail: risnasaswati@gmail.com 
uptake. The teacher continued by asking another expression to ask for information in Can you say I want to ask? The learner made an error since he/she should answer the question using a long answer. The answer 'No' was considered an error. Teacher noticed this and gave a clarification request. He/she needed the learner answered the question clearly not only using acknowledgement by saying No. As stated in (9), the learner did self-correction as the repair uptake after the teacher's clarification request to invite the learner told the reason. The teacher commented the learner's correct answer by using the metalinguistic feedback as in (10).

\section{Episode 5}

1. T: Okay, you also order from the car like in $\mathrm{McD}$. Now it's very very famous with the services of Gojek. What do you call it?

2. SB: Go food. (Error)

3. T : Go food. It's equal to? Go food is equal to? (CF-Elicitation)

4. S: Delivery food. (Uptake-RepairSelf-repair)

5. T: Delivery food.

6. T: You often ask of delivery services. (CF-Elicitation)

The data informed about the application of the elicitation by using question as the strategy used by the teacher as stated in (3). The learner made an error since he/she used the brand. In 4, it revealed that the learner attempted to correct the answer by self-repair. The uptake repair occurred since he/she could replace the brand by saying delivery food. Teacher repeated the learner's utterance to mark the correct answer and used metalinguistic feedback as stated in (6).

\section{Episode 6}

1. T: Ok, what else, that's one detail

2. S: The people like the people in a corporate. (Error)

3. T: How can you say? How can you know? Why do you think they looked corporate? (CF-Clarification request)

*Author(s) Correspondence:

E-mail: risnasaswati@gmail.com
4. S: Because they look seriously. (Uptake-Needs Repair-Off Target)

5. T: They what? (CF-Elicitation)

6. S: Seriously (Uptake-Needs RepairSame Error)

7. T: They...seriously is an adverb. They looked....

So, they looked serious or they looked seriously? (CF-Elicitation)

8. S: Serious (Uptake-RepairRepetition)

The sixth episode revealed that teacher applied the clarification request as his/her corrective feedback to clarify the learner's response as stated in (3). The learner's uptake was an error in linguistic form (in 4). The learner attempted to correct his/her erroneous form by repairing it. However, he/she made another erroneous form. The teacher employed the elicitation strategy to ask the learner corrected the error. The learner committed the same error as it was in (6). It was Needs Repair of the same error. To assist the learner, the teacher recast the linguistic form and combined the strategy by elicitation by giving the choices as found in (7). The learner successfully corrected the error made by choosing the correct linguistic form. The repair uptake occurred by repeating the teacher's correct utterance. The learner chose the best form as in (8).

\section{Episode 7}

1. T: Okay thank you that's enough. You have a question.

2. S: I have a question. (Error)

3. T: Can you say it please louder? (CFClarification Request)

4. S: I have a question. Are you always interested in a good looking and smart boys? (Uptake-Repair-Self-repair)

5. T: Okay. Are you always interested in good looking and smart boys? Say it again. (CF-Elicitation)

6. S: I have a question. Are you always interesting.... (Uptake-Needs RepairOff Target)

7. T: Interested. Owh come on. Listen to me. Are you always interested in 
smart and good-looking boys? Okay. Start. (CF-Elicitation)

8. S: I have a question. Are you always interested in good looking and smart boys? (Uptake-Repair-Repetition)

9. T: Very good. (CF-Metalinguistic Feedback)

In episode 7 as stated in (3), the teacher applied clarification request as his/her corrective feedback strategy to respond to learner's erroneous form. The learner attempted to correct the error. However, he/she made an error in another form. It was the Needs Repair uptake which needed the revision (4). The teacher supplied the correct answer by repeating the learner's utterance and asked the learner to repeat his/her correct form. The learner repeated the teacher's sentence but he/she made an error in form as the uptake needs repair as in (5). The elicitation strategy was applied again by the teacher to assist the learner differentiate the word, interesting or interested as in (7). The learner repeated the teacher's sentence and could successfully produce the correct sentence as the repair uptake (in 8).

\section{Discussion}

The teachers employed all the corrective strategies in correcting the erroneous utterances made by the learners. However, the findings revealed that there are corrective strategies which were effective to lead the learners' repair uptakes. The effective strategies for providing the corrective feedback for learners were the correct forms elicited (elicitation, clarification request, repetition, and metalinguistic cue). It was effective because it provided the learners opportunities to correct their erroneous forms. They attempted to formulate the correct forms. They attempted from Needs Repair uptake to Repair uptake. The corrective feedback strategies in the category of correct forms elicited made the learners notice their errors and correct the errors by themselves. They were not supplied the correct errors by the teachers. The learners' attempts to correct their erroneous forms were Needs Repair (the same error made, acknowledgement, off target) to achieve the Repair Uptake (self-repair, repetition and incorporation).

\section{CONCLUSION AND SUGGESTION}

\section{Conclusion}

The corrective feedback provided is to correct the erroneous forms that the learners made during speaking in classroom interaction. It is expected that the accuracy is achieved. Sheen (2011) categorizes corrective feedback into two segments: correct form provided and correct form elicited. The former comprises recast and explicit correction. The last category involves elicitation, repetition, metalinguistic cue, and clarification request. The study revealed that teacher employed varied types of corrective feedback to make the learners correct the erroneous forms. The correct forms elicited were employed more by the teachers to assist learners to repair the errors they made. Those used were clarification request, elicitation, repetition, and metalinguistic cue. Others were recast and explicit correction. The correct forms elicited were to give the opportunities for learners to notice their erroneous forms. It was found that learners attempted to repair the errors. They struggled to correct the errors and their attempts were categorized into Needs Repair. The teachers did not supply the correct forms; however, they asked the learners to try to correct the errors. It was different when correct form provided since the learners were spoon fed by the teachers. The effective strategies for providing the corrective feedback for learners were the correct forms elicited (elicitation, clarification request, repetition, and metalinguistic cue). The correction done by the learners was a process to develop their linguistic accuracy. The corrective strategies chosen by the teachers found in this study were to facilitate the learners to go through the process for the language development.

\section{Suggestion}

The teachers are recommended to vary the corrective feedback strategies to facilitate

\footnotetext{
*Author(s) Correspondence:

E-mail: risnasaswati@gmail.com
} 
learners to engage in classroom interaction. Additionally, it is to assist them to develop their language. The corrective feedback strategies suggested to be provided are the correct form elicited which comprises of elicitation, clarification request, repetition, and metalinguistic cue. Teacher should attempt to provide corrective feedback not only once and stopped the talk with one learner who made erroneous forms or incomprehensive answers; however, they should provide corrective feedback more until they are convinced the learners understand the points. Based on the evidences, corrective feedback strategies assist learners to repair their errors. The corrective feedback by correct forms elicited give opportunities for learners to correct their erroneous forms by themselves. Teachers are recommended not to supply the correct forms for the learners since it does not facilitate the learners to repair their erroneous forms. Learning is a process. It is suggested as well the teachers to provide uptake. Therefore, providing the opportunities for learners to repair the errors is a part of the learning process.

\section{REFERENCES}

Amalia, Z.D.H., Fauziati, E., \& Marmanto, S. (2019). Male and female students' preferences on the oral corrective feedback in English as a foreign language (EFL) speaking classroom. Humaniora, 10 (1), 25-33

Drew, Paul and Heritage, J. (1992). Analyzing talk at work; an introduction. In P. Drew and J. Heritage (eds.), Talk at work: interaction in institutional settings. Cambridge: Cambridge University Press.

Ellis, R., Basturkmen, and Loewen, S. (2001). Learner uptake in communicative ESL lesson. (2001). Language Learning, 51(2), 281-318

Ellis, R. (2008). The Study of Second Language Acquisition. Oxford: Oxford University Press.
Ellis, R. (2012). Language Teaching Research \& Language Pedagogy. Oxford: Wiley-Blackwell.

Jenks, Christopher J. and Seedhouse, P. (2015). International Perspectives on ELT Classroom Interaction. New York: Palgrave Macmillan.

Lier, L.V. (1984). Analyzing interaction in second language classroom. ELT Journal, 38(3), 160-169

Lier, L. V. (1988). The Classroom and Language Learner. London: Longman.

Liu, J. and $\mathrm{Xu}, \mathrm{Y}$. (2018). Interaction in the Classroom. The TESOL Encyclopedia of English Language Teaching, 1(1), 1-6

Lyster, R. et all, (2013). Oral corrective feedback. Language Teaching, 46 (1), $1-40$

Lyster, R., \& Ranta, L.(1997). Corrective feedback and learner uptake: Negotiation of form in communicative classrooms. Studies of second language acquisition, 19(1), 37-66

Suzuki, M. (2004). Corrective feedback and learner uptake in adult ESL classroom. Teachers College, Columbia University Working Papers in TESOL and Applied Linguistics, 4(2), 1-21

Phuang, Tran Thi Bich., \& Huan, Nguyen Bau. (2018). Teacher corrective feedback on students' speaking performance and their uptake in EFL classes. European Journal of Foreign Language Teaching, 3(3): 110-131

Richards, J. C. (2014). Approaches and Methods in Language Teaching. United Kingdom: Cambridge University Press.

Saswati, R. (2018). Analysis of classroom Interaction using IRF pattern: a case study of EFL conversation class. Scope: Journal of Language Teaching, 3(1): 29-37

Seedhouse, P. (1996). Classroom interaction: possibilities and impossibilities. ELT Journal, 16-23.

*Author(s) Correspondence:

E-mail: risnasaswati@gmail.com 
Sheen, Y. (2011). Corrective feedback, individual differences and second language learning. New York: Springer

Sinclair, J. and Coulhard, M. 1975. Toward an analysis of discourse. England: Oxford University Press.

Walsh, S. (2002). Construction and obstruction: teacher talk and learner involvement in

the EFL classroom. Language Teaching Research, 6:3-23

Walsh, S. (2011). Exploring Classroom Discourse: Language in action. Canada: Routhledge. 